\title{
A BINATIONAL APPROACH TO THE PALESTINE CONFLICT
}

\author{
Don Peretz*
}

\begin{abstract}
I
Binationalism Versus Exclusivity

Binationalism as a possible solution to the bitter conflict between Arab and Jewish nationalisms in Palestine is not a novel conception. Thirty and even forty years ago there were Zionists such as Dr. Judah Magnes ${ }^{1}$ and leaders of the Ha-Shomer ha-Zair movement ${ }^{2}$ who conceived of binationalism as a middle way toward resolution of the conflict. However, neither Palestine Arab nationalists nor most Zionist leaders found such proposals meritorious. By the end of World War II when the Biltmore program ${ }^{3}$ calling for a Jewish Commonwealth in Palestine had become accepted Zionist policy, and establishment of the country as an independent Arab state was the generally proclaimed goal of Palestine's Arab leaders, ${ }^{4}$ a binationalist compromise seemed even more remote. Extermination of ninety per cent of Europe's Jews, and intensification of Arab nationalism deepened the rift between the two groups of peoples. Zionists, with the support of most organized world Jewry, by and large declared willingness to accept less than all of Palestine rather than surrender to a shared sovereignty. They preferred a smaller but exclusive Jewish state in part of the disputed area to a diluted control within a larger region. Without complete sovereignty, they believed, it would be impossible to achieve their total national

- B.A. 1945, University of Minnesota; M.A. 1952, Ph.D. 1955, Columbia University. Professor of Political Science and Director of the Southwest Asia North Africa Program, State University of Nev York at Binghamton, N.Y. Author, Israer and the Palestine Arabs (r955); The Midde East Today (r963); The Middle East: Selected Readings (I968).

${ }^{1}$ Dr. Judah Magnes was an American Zionist leader who became the first president of the Hebrew University in Jerusalem. He was among the first and leading proponents of an Arab-Jewish or binational solution to the Palestine problem. He died in 1948, shortly after the partition of Palestine. Dr. Magnien' position is set forth in J. Magnes \& M. Buber, Arab-Jemish Unity, Testmony Before the ANglo. American COMmission fOR the IhUd (Union) Association (1947).

'Ha-Shomer ha-Zair (The Young Guard) is a Zionist youth movement established in Eastern Europe. Its founders became the leaders of the Mapam political party, a left wing Zionist socialist movement now represented in the Israel Parliament and government. It no longer supports binationalism. Sce I \& 2 Palestine, a Study of Jewish, Arab and British Policies (published for the Esco Foundation for Palestine, Inc.) (1947).

${ }^{8}$ The Biltmore Program was adopted at a Zionist conference held at the Biltmore Hotel in New York City during May 1942. It called for establishment of Palestine "as a Jewrish commonwealth." 2 id, at ror4.

'The principal leader of the Palestine Arab nationalists, Haj Amin al-Husayni, Mufti of Jerusalem and leader of the Palestine Arab Higher Committee, declared that "Zionists must not have an inch of this country" in 1947 at the time he and his followers organized a boycott and demonstrations against the inquiry into the dispute undertaken by the United Nations Special Commission on Palestine (UNSCOP). J. Hurevitz, The Struggle for Palestine 294 (1950).
\end{abstract}


aspirations and to guarantee the unlimited immigration of Jews to Palestine which had become a major goal following Hitler's extermination of their coreligionists.

Arab nationalists, too, aspired to exclusive jurisdiction of Palestine. This was evident in their rejection of binationalist proposals and by their insistence that Jewish immigration be so curbed that an Arab majority in the country would be guaranteed in perpetuity. ${ }^{5}$ It was so dangerous for any Arab of consequence to express public support for Magnes or his views that binationalism was labeled as merely another form of Zionist intrigue. Magnes himself has related that more than one of his Arab friends who dared openly to support binationalist views was either assassinated or otherwise effectively silenced through the use of violence.

The majority of United Nations members in 1947 recognized, in effect, Arab and Jewish demands for exclusivity of jurisdiction when they recommended partition of the disputed land. ${ }^{8}$ Whereas most Palestine Jews and their supporters abroad joyfully accepted this supposed compromise, the country's Arab majority and their conationalists insisted that denial of complete sovereignty violated indigenous rights.? While the United Nations recommendation failed to effect any measure of real compromise, it (for all practical purposes) made a binationalist solution politically unrealistic. By the end of the 1948 Palestine war the concept of exclusivity was further strengthened since the new nation of Israel was almost an exclusive Jewish state, with only a tiny, politically ineffective Arab minority. ${ }^{8}$ The remnants of geographic Palestine were exclusively Arab since no Jews remained in Egyptian occupied Gaza or what was to become the Hashemite Kingdom of Jordan's West Bank. Very soon most of the former proponents of binationalism accepted the new status quo and now characterized the idea as anachronistic.

There was little reason for political realists to remain loyal to the binationalist concept. It received no public support from any respected Arab leader or political group. On the contrary, the stated goal of most Arab nationalists remained recreation of an Arab Palestine to include the territory of the Jewish state. ${ }^{9}$ Both Arabs and Zionists retained the goal of complete sovereignty.

\footnotetext{
5Id.

- By its resolution $18 \mathrm{I}$ (II) the General Assembly endorsed the proposal of UNSCOP by a yote of 33 to 13 with 10 abstentions on November 29, 1947. The resulting Plan of Partition with Economic Union proposed to divide Palestine into a Jewrish state of 5,500 square miles (about $55 \%$ of the total area), an international enclave to include Jerusalem and an Arab state comprising the rest of Palestine. 2 U.N. GAOR, Resolutions 131, 132, U.N. Doc. A/519 (1947).

7 The Arab Higher Committee condemned the partition proposal as "null and void" and announced that it would refuse to participate in its implementation, calling on the British Government which held the Mandate for Palestine to turn the country over "to its Arab people." J. Hurewirz, supra note 4, at 3 ro.

${ }^{8}$ During the Palestine war of $1947-48$, some 725,000 Arabs fled from areas occupied by Israel, leaving approximately 161,000 within Israel's armistice frontiers out of a total population of $1,173,000$. Sratisrical ABstract of IsRAel 27 (1961).

${ }^{\circ}$ Although between 1949 and $x 964$ some Arab governments supported a compromise solution to the Palestine problem based on the U.N. partition resolution, at the Cairo Summit Conference of Arab Chiefs of State attended by delegations from Jordan, Algeria, Sudan, Iraq. Saudi Arabia, the United Arab Republic,
} 
Experience elsewhere since World War II is hardly encouraging to binational or multi-national concepts. In new states created since the war, and in older, long established countries formed from two or more national, ethnic, linguistic, or religious groups, it is difficult to find supportive evidence for harmonious relationships resulting from their fusion within a single state. Among the new African countries one can readily find discouragement for multi-national concepts in the recent history of Nigeria, the insurrection of southern Negro peoples against the Arab Sudanese government, the revolt of the Buganda tribesmen against Uganda, the disruption of the Congo, and the collapse of the Mali Federation caused by the withdrawal of Senegal in Ig60. In Asia recent experience is no more encouraging. Until today Burma is torn by conflicts between the Rangoon authorities and groups such as the Shans, Kachins, Karens, and others. Moving down the list of new Asian states to Indonesia, Vietnam, Laos, Thailand, Malaysia, and India the picture is also one of discontent, upheaval and failure by central authorities to maintain political equilibrium. Within the Middle East itself, the conflicts between Arabs and Kurds in Iraq, and between Greeks and Turks in Cyprus, indicate the extent of dissatisfaction within multi-national states. ${ }^{10}$

The longer-established Western nations offer little, if any, more hope. In recent months Canada and Belgium have captured world attention through their internal ethnic conflicts. And from the Soviet Union and Yugoslavia are heard rumors of dissent and dissatisfaction based upon national differences. It seems that one of the major political dilemmas facing the modern world is how to reconcile the claims of diverse groups within effectively centralized multi-national states. ${ }^{11}$

Returning to Palestine, we are here faced with similar dilemmas. On the one hand evidence from both Arabs and Jews during the last half century seems to point overwhelmingly to the impossibility of shared jurisdiction within a single political entity. Their continued demands for exclusive jurisdiction in the disputed territory of Palestine militate against compromise. Yet without compromise over the crucial question of jurisdiction, even an easing of tensions, to say nothing of solution, does not seem to be in view. Continuation of the status quo in political relationships

Yemen, Kuwait, Lebanon, and Libya (i.e., all Arab League states except Tunisia and Morentu), during January 1964 , those present unanimously agreed to organize "the people of Palestine to enable them to liberate its homeland and determine its future." See L. Kadi, Arab Sumuit Confenences and tuIE Palestine Problem (1936-1950) (1964-1966) (Palestine Books No. 4, 1966) (Research Center, Palestine Liberation Organization, Beirut).

${ }^{10}$ For a survey of the question "Can two or more self-differentiating culture-groups co-exist within a single political structure?" see Connor, Self-Determination, 20 Worzd PoLirics 30 (1967).

${ }^{11}$ In Nigeria, for example, it is difficult not to sympathize with the plight of the Biafrans, for their secessionist state is formed from an attractive, intelligent, and creative people. If allowed to pursue its own policies free from outside intervention, Biafra may well have developed into a viable and progressive country. Yet international opinion has overwhelmingly supported the central government in Lagos in opposition to Biafran claims for exclusive national jurisdiction within their territory. Most African nations, Nigeria's former British administrators and the major world powers of both East and West oppose the secessionist state. Does this implicitly mean support for multi-nationalism as the lesser and least disruptive of choices? 
threatens not only Arabs and Israelis, but the political equilibrium of the entire international community. While Arab and Zionist nationalist claims remain irreconcilable, the superpowers and even lesser states with aspirations for influence in the Middle East are attracted to support one side or the other. The result is that Palestine has tiecome a major area of tension in the competition and conflict among world powers and among nations which aspire to become powers.

Often the key issue in the Palestine conflict has been lost sight of, and symptoms have been regarded as causes of continued tension. Most obvious in this diversion has been the attempt to isolate subsidiary or secondary issues such as the refugee problem, borders, the status of Jerusalem, and division of the region's scarce water resources. But, failure to bring Arabs and Israelis to agreement on any of these issues is symptomatic of the key problem of jurisdiction over the territory of Palestine. ${ }^{12}$

II

\section{A Binational Plan for the Future of Palestine}

The Arab-Israeli war of June 1967 radically altered the dimensions of this jurisdictional conflict, although not its essence. The Israeli victory placed Zionist nationalism in a rosition where it controls and for the time being has exclusive jurisdiction over all the disputed territory. On the other hand, victory radically altered the demographic aspect of the problem. ${ }^{13}$ The territory under Israeli jurisdiction is no longer innabited by a nearly exclusively Jewish population. It is now inhabited by two principal national groups, Jews and Arabs. ${ }^{14}$

\footnotetext{
${ }^{10}$ The literature on these various aspects of the Palestine problem is vast. For a summary statement on their significance, see Peretz, Israel and the Arab Nations. in J. Thompso: \& R. Reischauer, ModerNization of the ARAB World i66 (Ig66).

${ }^{13}$ The territory occupied by Israel during the June 196; six-day war included the Gaza Strip and the West Bank of Palestine between the armistice frontiers and the Jordan River. The former was Egyptian-occupied territory, while the latter had been incorporated into the Hashemite Kingdom of Jordan during 1949. In addition, Israel accupied the Sinai Peninsula and the Golan Heights of Syria. The total occupied arca was thus three or four times that of Isracl. According to the latest issue of the Israel statistical yearbook published by the Israeli Government in Jerusalem, as of September 1967, the population of the state, including East Jerusalem, totaled 2,758.400 people, of whom 2,371, I0o were Jews. The population of the occupied areas, according to a government census, totaled 995,000, of which 599,000 lived in the West Bank: 365,000 in the Gaza Strip; 33,000 in Northern Sinai, and 6, 400 in the Golan Heights. This was considerably smaller than the Arab population of these areas before June 4 . 1967, due to the exodus of about 250,000 refugees, mostly from the West Bank. See Ecoxomic Plasising Authority, Prime Minister's Office, The West Bank: An Economic Survey (Hebrew) (Jerusalem, I967).

14 There are many who argue that the Jews are not a national group but a religious group. This, however, seems to be a rather theoretical argument that non-Israelis may fruitfully discuss in a philosophic rein. The Jews of Israel do constitute a national group in the light of all modern concepts of the term nation, that is, they are a group with a common language, and religion, and even more fundamentally, a group which identifics with a common past, present, and future, a self identified group. Jew's abroad may or may not choose to identify with their coreligionists in Israel as an extension of the "Jewish nation." Many have chosen to be so identified. a few have renounced such national identification, and most others remain ambivalent and confused about their identity with fellow Jews in Israel.

Ironically, many Zionists dispute Arab claims to national status, charging that the Arab world is a
} 
While the June war brought great tragedy to the region, increasing by thousands the number of dead and wounded victims of the conflict, and greatly increasing the number of refugees and displaced persons, both Arabs and Jews, it may also offer hope of an alternative to continued strife over the exclusive jurisdiction of Palestine. ${ }^{16}$ Failure to take advantage of this opportunity will probably lead to renewed warfare, thousands of additional victims and increased numbers of refugees. ${ }^{16}$

The approach to an easing of tensions that I propose here is not intended as a definitive solution to the Arab-Israel conflict. Nor am I hopeful that it will find support among any substantial number of Arabs or Jews. My intention in making these suggestions is to stimulate new lines of thought. It might be useful for those concerned with this conflict to think in other than conventional terms about its solution. I realize the obstacles and difficulties in turning to new lines of thought in connection with this or with any major international problem so beclouded by emotion and fierce partisanship. In the case of Palestine discussion of solutions which go beyond the conventional framework of a Jewish or an Arab state is often suspect and therefore cast aside as irrelevant. Thus there are few Jews and even fewer Arabs who have begun to re-examine the conflict in the hope that some new approach may be applied. ${ }^{17}$ I would like to further encourage those somewhat visionary individuals who have thought in unique terms about solutions, and to encourage others to give more serious thought to their ideas and suggestions.

Obviously Israeli Jews and Palestine Arabs will not, nor could they, create a binational state tomorrow, or even perhaps within the next decade. The deep suspicions, mistrust, and hatreds that separate them would be enough to prevent their cooperation in any effort which so closely touches their vital existence. Furthermore, there are great practical obstacles to fusion in a single political entity in the near future. The economic and cultural gap between Israeli Jews and Palestine Arabs is far wider than the gaps which separate other disparate groups which have unsuccessfully tried to unite politically in recent years. Israel is today a Western

diverse region devoid of any real national character. But the same standards apply to Arabs as well as Jews. By and large the Arabs are self-identified as a national group with common attributes in language, a historical past, present and future, despite their division into a congeries of many different political forms.

${ }^{15}$ There have only been estimates of Arab casualties in the June war. They indicate that Egyptian, Syrian and Jordanian military dead and wounded totaled tens of thousands. These included some 5,000-10,000 Egyptian soldiers killed in Sinai and about 6,000 Jordanian soldiers killed or missing in the West Bank. Israeli dead were approximately 700 and seriously wounded only about 2,500. See Facts on File, Keesings Contemporary Archives, and the New York Times for June through October 1967.

${ }^{10}$ The total number of refugees is estimated at about 250,000 in Jordan, 125,000 in Syria, 30,000 in the United Arab Republic, and 300,000 displaced persons from the Suez Canal Zone. The number is not constant since there was a continuing displacement of Arabs from Israel to Jordan at the rate of 7,000 per week in the months immediately after the war. See Peretz, Israel's New Arab Dilemma, 22 The Middie EAST Journst 45 (1968); Report of the Secretary-General Under General Assembly Resolution 2252 (ES-V) and Security Council Resolution 237 (1967), U.N. Docs. A/6797 and S/8158 (1967).

${ }^{17}$ For various approaches by different Israeli groups to the problems following the six day war, sce volumes to and $1 \mathrm{I}$ of New Outlook, a Middle East monthly published in Tel-Aviv, Israel. For a new Arab viewpoint, see Hourani, The Moment of Truth, Excot:vrer, Nov. 1967, at 3. 
oriented, European nation. Its vital statistics in matters such as literacy, birth and death rates, level of per capita income, occupational distribution, taxation, social welfare and public expenditure, indicate that it is much more of the West than of the Arab world. ${ }^{18}$ While tens of thousands of Palestinians have made great strides in improving their individual material status, in increasing the level of their technological and scientific sophistication, and in broadening their world outlook during recent decades, the Palestine Arab community is still largely a rural, peasant community, more of Asia than of the West. Although tens of thousands of Palestimians have acted as leavening agents in the progress of the Arab world since the 1950s, the greater number of Palestinians who remained in Jordan, and in the areas now occupied by Israel, are members of a traditional community with an outlook on the world and a philosophy of life which are quite at variance with those of their Israeli neighbors.

Therefore no political realist could conceive that these two disparate groups of people could be hastily fused into a single state-even if such fusion were the only answer to their conflicting claims for the territory which they both hold dear.

Although these groups are so vastly different, the fact that they live so closely and in some places so intermixed, necessitates their interaction. Until today, interaction between them has been marked more by violence or the threat of violence than by peaceful cooperation. Because each side has feared its ultimate national extinction, each has demanded, and has fought for, exclusive jurisdiction over its territory and the people within that territory. For each side the struggle has been a matter of national life or death. With Israel's victory in June, the concept of Palestine as a national entity, a state in which Palestinian Arabs would have exclusive sovereign:y, seems to have died-thus the rallying cries by most Arab nationalists of support for Palestinian underground fighters. There is the hope that violent actions will keep alive the sparks of a Palestinian national consciousness, and the concept of a Palestinian Arab political entity. ${ }^{19}$

However, is the absolute sovereignty for which Zionists and Arab nationalists have been fighting a sine qua non for realization of their ultimate goals, or for continued existence? Could the Arab life or the Jewish life toward which nationalists aspire be lived in a state where the respective groups do not have exclusive political jurisdiction, in a state where political sovereignty is shared? Are a Palestine Arab army, or a Jewish military complex, a predominantly Arab or Jewish parliament or civil service, essential to guarantee that Arab children go to Arab schools, that Jews lead fully Jewish lives, that cultural images and symbols and historical nostalgias are not forgotten?

\footnotetext{
${ }^{18}$ For a comparison of differences between Israel and West Bank Arab demographic and economic status, see Sheshkin, Economic Structure of the West Bank, New Outzook, Sept.-Oct. 1967, at 20.

${ }^{20}$ Shammas, Armed Struggle is the Only Way, Beirut Star, Feb. 4, I968, an article on possibilities of merging Arab commando units. See also No Alternative (editorial), Beirut Star, Feb. 25, 1968.
} 
It seems that continuation of present tensions will lead to renewed warfare in which the creative aspects of Jewish and Arab culture will become secondary to military culture. In their quest for political exclusivity, both peoples will be forced to surrender many constructive aspects of their national lives. As the science of warfare and military technology become increasingly complicated and prohibitively expensive, ever larger amounts of indigenous talent, national wealth, and public effort will have to be channeled into defense of exclusive political rights. It would indeed be an ironic twist of history if for the sake of maintaining an exclusively Jewish army to protect an exclusively Jewish state, traditional Jewish learning were lost. Yet this is no remote possibility. Today both Israel and its Arab neighbors must make great sacrifices to keep the right of exclusive national jurisdiction. In less than a week in June 1967 the United Arab Republic alone lost military equipment and supplies whose value was nearly that of the High Nile Dam, ${ }^{20}$ a project in which that nation had invested a decade of its best talents and major resources. The cost of the war to Israel has been estimated at nearly one-third that amount, or the price of several Hebrew Universities, a landmark, which if it is permitted to endure, will be of far greater significance to the world as a symbol of Jewish accomplishment than victory in the Six Day War, or than the Jewish army which exists to defend exclusive political jurisdiction.

Switzerland is an instructive historical case in which political jurisdiction does not necessarily mean dilution of cultural or religious life. If sovereignty in Palestine were shared in a similar fashion between Jews and Arabs the billions spent to defend or to acquire exclusive jurisdiction could be used to raise substantially both Jewish and Arab national prestige and to preserve and strengthen Jewish and Arab national cultures through greatly expanding the number of Hebrew and Arab universities, the Hadassah medical complexes, and the High Nile, Euphrates, and Jordan dams. ${ }^{21}$

However, as history has shown, where great emotional commitments and investments have been made, even the most rational men often find that that which is rational seems to be beyond their accomplishment. Indeed, it may often seem to be irrational since it does not conform to their own conception of orderly processes

\footnotetext{
${ }^{20}$ Estimates of the value of military equipment lost by Egypt in the June war range between one and two billion dollars. President Nasser informed an interviewer from Look magazine that $80 \%$ of the Egyptian army was lost. Israel's finance minister reported the cost of the war to Israel at about $\$ 750$ million. I967 FACTs oN File 500; Attwood, Nasser Talks, Look, March 19, 1968, at 61.

${ }^{21}$ Under the Swiss system, governmental powers are divided or shared by federal authoritics and twenty-three cantons which make up the Swiss federation. There are major linguistic, religious and economic differences between the cantons so that each canton or group of cantons has vital interests and cultural orientations which are distinctive from those of its neighbors. While under the old confederation from $\mathrm{I} 29 \mathrm{I}$ to 1798 , there were serious disagreements among these diverse groups, occasionally resulting in war between them, since the mid-nineteenth century they have been able to reconcile their differences in a federation that has withstood the strains of European wars betwcen nations which had the sympathies of one or another group of Swiss. See The Federal Constitution of Switzerland (C. Huges ed. 1954).
} 
and ideal solutions. Therefore, I do not propose that Arabs and Israelis meet tomorrow at a drafting table to plan the liquidation of their exclusive national claims.

While a binational state in Palestine is unattainable in the immediate future, there are steps toward such a solution that many could accept who otherwise disagree with the binational principle. One such step has already been taken in placing the disputed territory and its strategic hinterlands under a single political authority. In ordinary circumstances this step could not easily have been realized. It is one of many results of a cataclysmic disaster. Other results of the disaster cannot be modified, such as restoration of the thousands of lost lives, or replenishment of the billions of wasted dollars. The placing of Palestine under a single political jurisdiction could be altered in a variety of ways. One would be to restore the status quo that existed on June 4, 1967. However, restoration of that status quo would not substantially improve the lot of most people affected by the conflict. Israel would gain little if anything by restoration of the pre-June military situation. Most of the Arab refugees would still be refugees, and those who were not would return to a situation still filled with tension, and the continued possibility if not probability of war. Another alternative, suggested by some Israelis is incorporation of all, or parts, of the so-called occupied territories within Israel. Obviously this is unacceptable to Arabs, as it is to many Israelis. It would not guarantee peace. On the contrary, it would lead to an upsurge of Palestinian Arab irredentism and the outbreak of increased guerrilla activity against the Government of Israel. A third alternative would be establishment of a binational state now. But since neither Palestinians nor Israelis are yet ready for the cooperation prerequisite to the peaceful operation of a binational state, this alternative is not now feasible.

An effective step at this time might be to change the juridical status of occupied Palestine with the consent of the people who live there and who consider it their home. Many local government functions are presently being carried out in the occupied territories by Palestinians who carried them out when the territory was governed by Jordan. ${ }^{22}$ Might it not be possible to increase these functions with a view to developing a total system of self-government by Arab Palestinians? This could have appeal to inhiabitants of the occupied territories only if the symbolism of occupation ceased to exist. To win Arab cooperation for peaceful and mutually beneficial

\footnotetext{
${ }^{22}$ Prevailing policy of the Israeli military government is to comply with the 1949 Geneva Convention Relative to the Protection of Civilian Persons in Time of War. In esserice this means continuation of the status quo in local administration and reflects the following general principles: (a) the limited and temporary nature of occupation; (b) that sovereignty is not vested in the occupation, (c) that the prime duty is the establishment of order in the occupied area, (d) that the minimum alteration should be made to the existing administration, economy, legal system and general life of the occupied community, and (c) that the minimum is to be determined by the restrictions and changes properly imposed for the security of the occupant's armed forces and civil administration.

Early in 1968 Israel stated that the territory occupied in June would no longer be called "enemy territory," leaving its status in limbo and arousing Arab suspicions that it would be incorporated into Israel. N.Y. Times, March I, 1968, at I, col. 4 .
} 
development of the West Bank, military occupation would have to be demilitarized. Planning for the occupied areas can be effective only if undertaken with Arab cooperation. ${ }^{23}$ If it is merely imposed upon the inhabitants it will no doubt be resisted.

The Arabs of Palestine also have responsibilities if they desire to avert continued bloodshed and warfare. They cannot expect self-determination at the expense of Jewish lives or Israeli security. It would be unreasonable to expect termination of Israel's occupation policies without assurance that cessation of these policies will also mean an end of Arab guerrilla warfare against Jews. If there were to be a quid pro quo for ending the guerrilla warfare, it might be expected that Palestinian Arab leaders could terminate it in the interest of their own and their peoples' welfare.

Jerusalem is a key to improved relationships between Israelis and Palestinian Arabs. . Few, if any, of the city's 65,000 or 70,000 Arabs have reconciled themselves to becoming Israeli citizens. ${ }^{24}$ There is not one Arab leader who has accepted this status. Without an accommodation between the Arab and Jewish inhabitants of Jerusalem, accommodation elsewhere is hardly likely. A status imposed by one side on the city is not an accommodation and will only exacerbate the existing tensions, inflame irredentist sentiments, and encourage Arab guerrillas and their supporters. Accommodation is possible without rebuilding the barriers that walled off Jews and Arabs from contact during the past twenty years. However, it does not mean complete and utter submission to the conquerors. Jerusalem might well become the testing ground for binationalism by making it not merely a Jewish but a joint capital for the Jewish sections of Palestine now called Israel, and for the Arab sectors which could be made self-governing. Within Jerusalem, Arab city officials who were responsible for Arab sectors of the city before June could continue to be responsible in the same way and with the same authority that they held then. Jewish officials could continue to manage their sectors of the city without surrendering any of its Jewishness. A major difference would be that all Palestinians, Jews and Arabs, and all non-Palestinians who desire to visit any sector of the city would be permitted to do so. Many municipal services such as water, electricity, sanitation, and the like would be jointly planned and operated for the city as a whole. Palestinian Arabs would again become responsible for Arab education, and for maintaining cultural and religious aspects of life that had previously been their responsibility.

If Arabs and Jews could effectively cooperate in Jerusalem, reaching mutually satisfactory accommodation there, might not the example of their efforts be applied in other parts of Palestine where the Arab population is essentially similar in its

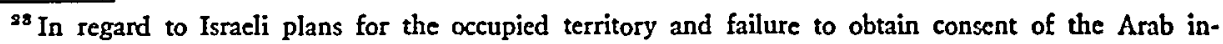
habitants, see Peretz, Israel's Administration and Arab Refugees, 46 Foreign Afratrs 336 (1968).

${ }^{24}$ On Jerusalem Arab attitudes toward the Israeli "integration" of Arab and Jewish Jerusalem, see statement by former Mayor of Jordanian Jerusalem, Rouhi al-Khatib, N.Y. Times, March 20, I968, at II, col. r.
} 
cultural-linguistic patterns and nationalist outlook? If accommodation fails in Jerusalem it is unlikely to succeed elsewhere for similar reasons.

A further step toward developing cooperation among the two peoples might be establishment of a Palestinian Arab parliament, to parallel the predominantly Jewish Knesset. ${ }^{25}$ This parliament could be entrusted with forming a government for the largely Arab areas of Palestine, including those in Israel such as Nazareth or the Little Triangle adjoining the former Jordanian frontier. If this body were entrusted with responsibilities for education, social welfare, and other such matters on behalf of all Palestine Arabs, its authority need in no way derogate from the responsibilities which Jews feel they must necessarily carry in order to preserve their Jewish life and culture. I am not suggesting that this diffusion of responsibility take place tomorrow or the day after, but only after it has been attempted on a small pilot scale in Jerusalem where it could now be undertaken unilaterally with agreement by Israel and the Arab population of the city.

Certain national functions might be delegated by the Arab and Jewish parliaments to a central federal authority or third parliamentary body which would represent both Arab and Jewish communities. Representation in this body might be based on the present numerical division in the country between Jews and Arabs, or it might be fixed constitutionally so that both national groups had equal representation. What if a deadlock were to occur at the federal level between Jews and Arabs? I am sure that if such a system were imposed today, there would be deadlock. But if both Arabs and Jews realize within the next few years that their demands for exclusive jurisdiction will lead only to renewed warfare, and if both sides are willing to experiment with a peaceful accommodation in Jerusalem, then the way will be paved toward the binational entity that has been briefly outlined here.

A question may well be asked about the fate of Jordan in such a visionary scheme. It is Jordan which has suffered more than any other country from the June war. Even before Jerusalem and the West Bank were torn away from Jordan there was serious question about the country's viability. Now the question is even more serious whether Jordan can remain a viable state without half its population and the major source of its sparse foreign currency earnings. ${ }^{26}$ An additional step in the longterm process outlined above might be inclusion of Jordan as a third partner in the proposed federal state of Palestine. ${ }^{27}$ Jordan, with its large Palestinian population, and Arab Palestine might again become a single entity within the larger federation. In either case, Jerusalem could again become an Arab capital shared with Israel

\footnotetext{
${ }^{25}$ Although there have been five and eight Arabs in the $120-$ member Israel Knesset, they are either tied to the Zionist Mapam or Mapai party or to the Communist Party. Only the latter is considered by Arabs to represent Arab interests; therefore, although there is formal representation of the Arab community of Israel in parliament, it is not considered by most Arabs to be truly representative.

${ }^{10}$ See Report of the Secretary-General, supra note 16, at 76-89; Beeson, Hard Times for fordan, Beirut Star, Feb. 5, 1968.

${ }^{27}$ The Swiss Cantonal system might be instructive. See generally The Federal Constitution of SWITZERLAND (C. Huges ed. I954).
} 
under two flags. The establishment of a rudimentary common market between Israel, Jerusalem, the West Bank, and Jordan, authorized when Israel re-established trade and commercial links across the Jordan River, may be the first unwitting step toward the proposal which is outlined above. ${ }^{28}$

Modification of the concept of exclusive jurisdiction along the lines I have proposed would resolve many of the problems that have plagued the area in the form of the so-called "Palestine dispute." Steps toward shared sovereignty would resolve questions about Israel's borders disputed by its Arab neighbors since the 1949 armistice agreements. With Jerusalem as a joint capital, the dilemma of internationalizing the holy city and its surrounding holy sites could easily be settled since they would be the special preserve of no single religious group. Some eighty per cent of the Palestine refugees and their offspring would be home again in a binational Palestine within the borders of the present Israel-occupied territories.

To become a vital and effective political organism a binational Arab-Jewish state would have to guarantee complete equality to all its citizens, giving special prerogatives to no single group. Complete equality in cultural, religious, linguistic, and political affairs would in effect mean that a binational state would no longer be merely a Jewish, a Zionist, or an Arab state, but a nation of diverse but similar groups. Such a nation would no longer be that nation which has been the target of Arab nationalist antagonism for over two decades. ${ }^{29}$

A binational state could not come into existence unless there were peace between it and its Arab neighbors. Without peace, it would constantly be torn by religious and ethnic dissension as each group sought to impose its will on the other. Only if such a state could be guaranteed free access to all waterways, freedom of trade and communications, and security of its borders could it flourish. Great power guarantees ending the disastrously expensive arms race and assuring economic assistance to the old and new Arab refugees would be required.

If it were to flourish, such a state could make major contributions to economic, cultural and social development of the Middle East, for as Israeli scientists and scholars lend their services to other nations in Asia, Africa and Latin America today, they could in a peaceful Middle East as citizens of a binational Palestine lend their services to the whole Arab world. The Arab world could contribute much to a truly Middle Eastern binational Palestine by assisting it to integrate into and to become part of the region. The economic union envisaged between binational Palestine and Jordan giving the latter access to Mediterranean ports and to its agricultural, mineral, and industrial resources now in Israeli hands could well be the foundation for a greater Middle East common market.

True, this vision of a peaceful Middle East may seem as much a fantasy as a

\footnotetext{
${ }^{28}$ Trade barriers are being lifted gradually. See Ha-Aretz and Jerusalem Post, Aug. 1967-Feb. 1968.

${ }^{20}$ See Peretz, Israel and the Arab Nations, supra note 12, for discussion of causes of Arab animosity to Israel.
} 
Soviet-American detente, or as a world without war. Is there, however, a peaceful alternative? Can peace be imposed on the Arabs by a militarily powerful Israel, or can an Israeli withdrawal imposed by a combination of world powers bring peace and security to the area? The region has been torn asunder by the continuous struggle between Zionist and Arab nationalisms for nearly half a century. Only if these two nationalisms can devise a new formula for living together can they avoid a fourth round of even more destructive war within five, ten or twenty years! 